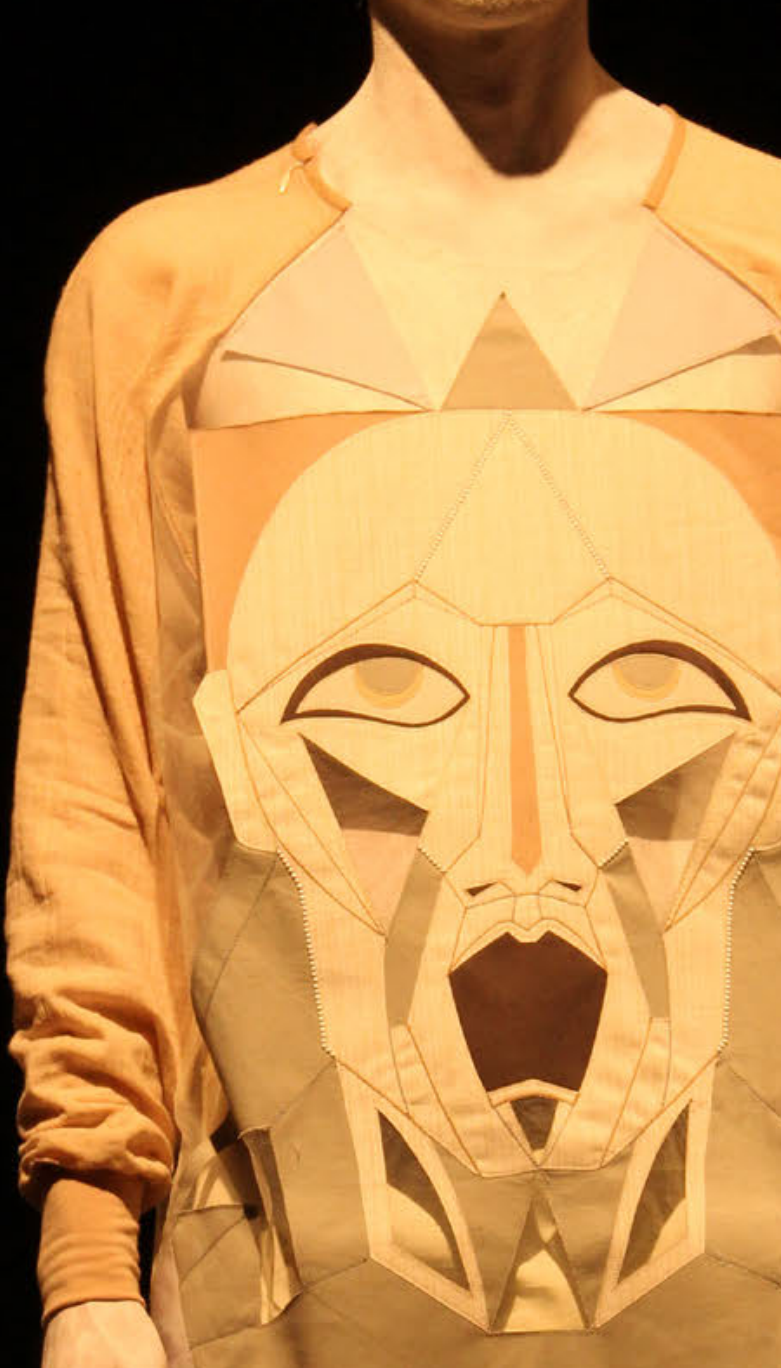

\title{
El diseño
}

de modas

mexicano

como lenguaje

museal

¿Pasarela,

museo

o teatro?

Gustavo Prado 

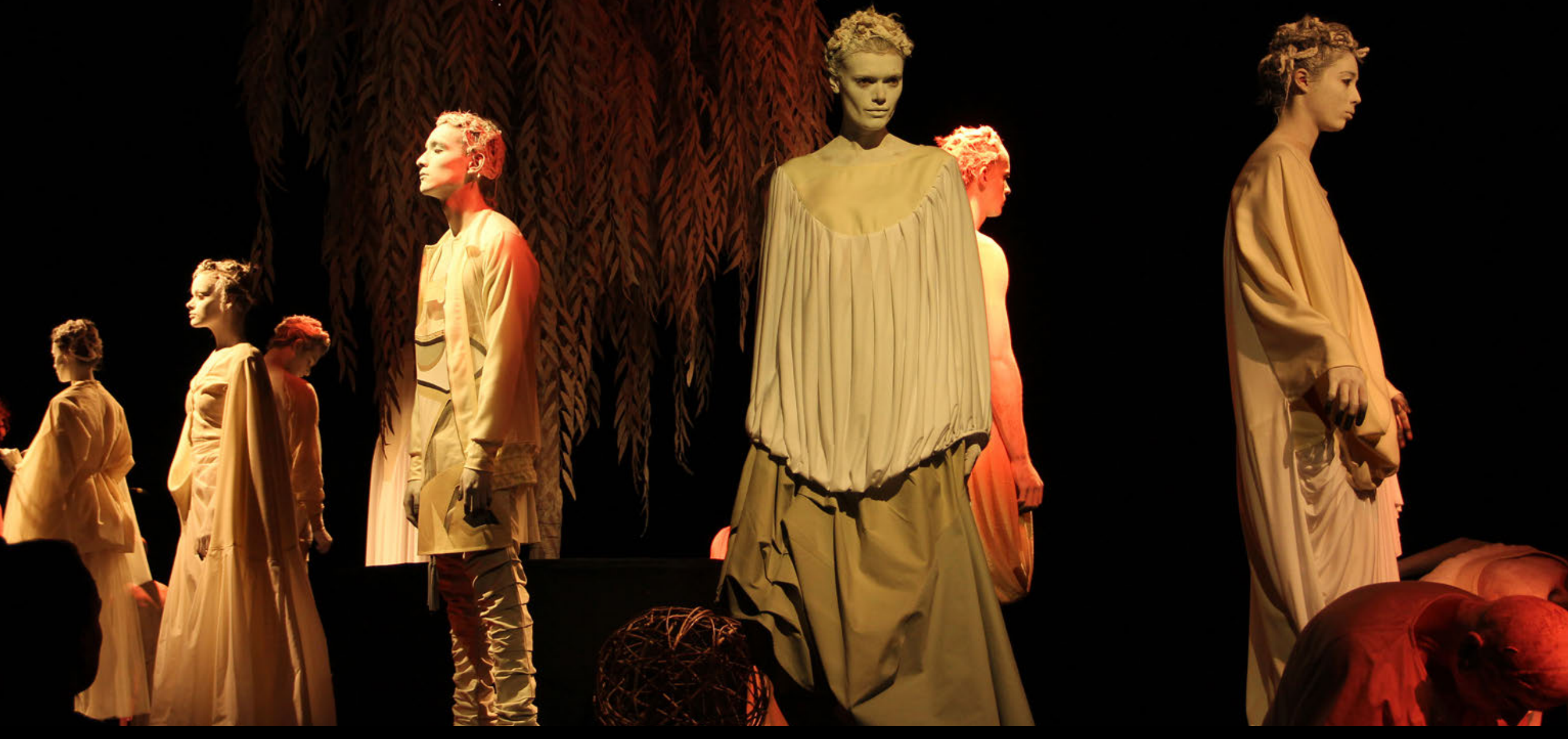
La museografía, es decir: ... el conjunto de técnicas desarrolladas para llevar a cabo las funciones museales y particularmente las que conciernen al acondicionamiento del museo, la conservación, la seguridad y la exposición (...), de manera más general ha dado en llamar 'panorama museográfico' engloba la definición de los contenidos de la exposición y sus imperativos, así como el conjunto de vínculos funcionales que existentes entre los espacios de la exposición y los restantes espacios del museo incluye las decisiones relativas a qué es lo que se exhibe, de qué manera y cómo se vinculará la propuesta con el público.

El arte es el lenguaje obvio que se dirime mediante esta forma de codificación, si bien desde los noventa hay una tendencia creciente a asociar las funciones museales con nuevos discursos y objetivos, que se expresan lo mismo en el Museo del chocolate, que en soluciones más obvias y necesarias como la moda, encarnación de la cultura, forma de expresión de la realidad cotidiana. En ese sentido se crearon en México espacios como el Centro de la Imagen, Arte Alameda, más recientemente el Centro de Cultura Digital en la Estela de Luz; que tienen como denominador el desarrollo de nuevos conceptos museográficos, ad hoc a las nuevas formas de expresión estética. En esta década ese mismo camino es el que recorrerán los diseños, y en particular el diseño textil y la moda.

El público, las prendas, la pasarela, son elementos que se han asociado con la moda por lo menos desde principios del siglo XX, cuando los modistas franceses Madeleine Vionnet y Paul Poiret tomaron la idea de llevar los maniquíes que exhibían las prendas en los escaparates a los salones en el interior de sus casas, con lo cual se estableció la presentación de la moda como un ritual que trasciende el mero paseo con ropa; la propia esposa de Poiret hacía las veces de su maniquí viviente en los círculos sociales que frecuentaban, tal como lo hiciera su precursor Jacques Doucet con Cecile Sorel y Sarah Bernhardt (Cerrillo Rubio, L. 2010). Estas estrategias sin duda contribuyeron a originar las pasarelas como un acto de exhibición con fines comerciales.

El acervo de la Fototeca Nacional de México incluye imágenes de desfiles realizados en El Palacio de Hierro durante los veinte, la década de las flappers (Martínez Gutierrez, P. 2005). Otra imagen recurrente en el imaginario nacional en relación a la moda en México es la película Modisto de señoras (Cardona, 1969), protagonizada por Mauricio Garcés. A partir de los ochenta, las pasarelas nacionales tienden a condensarse en descalabros inconsistentes que cambian de nombre año con año.

El público, las prendas, la pasarela, ¿para qué se realizan estos eventos? Desde mi punto de vista, se trata de escenarios en los cuales se expresa la consciencia colectiva en búsqueda de personajes centrales: lo que debería ser una presentación para clientes en donde se despliega la habilidad del diseñador para posicionar su marca dentro de un mercado, se queda en presentaciones donde el protagonista es el público desesperado por contar con un asiento en la primera fila —un público que con frecuencia no incluye a los compradores-, en el cual se ubican los bloggers que no son usuarios habituales de las prendas del autor, así como los medios especializados cuyas notas se decantan en la sección de sociales, lejos de la crítica de diseño (Carter, M. 2003). El contenido de las pasarelas, pues, se queda en éstas, sin que logren concretarse asuntos cruciales como la diversidad de tallas, la producción masiva, la posibilidad de repetición, la estrategia de distribución, entre otros.

Un nuevo giro se manifestó en México durante el 2013 en lo que hace a la relación entre la masificación de las audiencias, las prendas y las "pasarelas", que más que pasarelas, se transforman en videos de YouTube. Tal es el caso de Malafacha —el dueto mexicano de moda de vanguardia-, cuyo desfile primavera-verano 2014 fue presentado en la plataforma en línea Google+Fashion México. Una colección de volúmenes que asemejan al disfraz de un fantasma, acompañados por un baterista en vivo: sería un concepto bastante convencional de no ser por la ausencia de público en el mismo contexto espacio-temporal de la pasarela, grabada en estudio, transmitida en streaming con la posibilidad de ser vista en tiempo real o reproducida incontables veces a posteriori en YouTube.

La iniciativa Google+Fashion México fue concebida por Anna Fusoni, promotora, crítica, organizadora de encuentros de moda, una suerte de curadora; como una forma de salir del formato tradicional de pasarela sin llegar al planteamiento de museo. La feliz consecuencia de esta decisión sería la democratización del evento de moda, que más allá de la carrera por conseguir entradas para un desfile, ofrece la posibilidad de la memoria como acicate para la discusión, a la par que como dispositivo para la difusión de la marca. Ya personajes como Rick Owens, Gareth Pugh y Tom Browne han referido a las ventajas derivadas de la transmisión de pasarelas por internet, que incluyen la masificación de las vistas, la proliferación de comentarios en redes sociales y la pre-eminencia del diseño y del autor como centro de la propuesta:

The wait at Thom Browne's show seemed interminable. Fifty solid minutes of listening to music-box tinkling in a white Chelsea gallery with white padded walls, flickering lights and headless white mannequins hanging from the ceiling. As more than one person noted on Twitter, it was like being in an insane asylum (Wilson, 2013). 

ya lo etnográfico, reproduce la propuesta del segundo piso del Museo de Antropología, que recalca el traje "mexicano" en un sentido estereotípico.

La experiencia más cercana a una propuesta museal especializada en moda ocurrió en El Palacio de Hierro a finales del 2013: abarcando toda la tienda, un andamiaje mostró piezas de época para conmemorar los 125 años del emporio; desde lámparas Art Nouveau hasta línea blanca de los cincuenta, rematados por vestidos desde el siglo XIX hasta la actualidad, incluyendo a Gaultier, De la Renta y Pucci (López, F. 2013) .

En este mismo tenor, con pocas semanas de diferencia en relación a Google+Fashion, el Mercedes Benz Fashion Week 2013 (presentó la iniciativa The Box, con la cual se invirtió la propuesta tradicional del desfile; para cerrar el día inaugural los diseñadores del dueto mexicano Trista presentaron su más reciente colección. Cada atuendo llevado por una modelo con la mirada perdida lucía en un pequeño pedestal para ser escrutado con detalle, un tableau vivant que puede ser observado con más cercanía que una pieza de museo: el espectador y el voyeur se encuentran. A modo de conclusión, un enorme telón cayó para revelar un andamiaje en el que diseñadores y protagonistas del ámbito de la moda estaban ataviados con Simple by Trista, su línea más accesible. Como actores que se presentan al final de una obra, retando al público, el espacio se fundió a negros. Inaugurando el happening en la moda nacional este mensaje fue muy comentado, pero sólo quedó en la experiencia y la memoria de quienes estuvieron presentes. En este mismo contexto, Malafacha, inspirados en la danza Butoh, presentaron su colección "En el sauce la mariposa", desplegada sobre una gran plataforma circular el centro de The Box, en una atmósfera enigmática, con modelos estáticos cuyo lenguaje corporal y proxémica remiten más a la experiencia teatral que a los códigos museales.
Estas propuestas dan cuenta de una tendencia que convierte la pasarela en una experiencia que oscila entre el museo y el teatro, que hace al espectador desplazarse entre las prendas, a la inversa en relación a la lejanía conceptual y vivencial de la pasarela en sus orígenes.

¿Qué pretende renovarse con estas iniciativas? ¿El mercado, la experiencia del espectador, la idea de interacción con la prenda? No debe extrañarnos que en la escena mexicana, tanto Trista como Malafacha destaquen por su efectividad para lograr narrativas grandilocuentes, que toman la moda como punto de partida para ensoñaciones con las que el público puede relacionarse, de las cuales puede apropiarse, para después usar, de esa idea global, lo que queda como prenda.

En suma, aludimos a nuevos caminos del lenguaje de la moda para pensarse a sí misma.

Algo de especial interés llama la atención: la inmediatez de los medios digitales agrega a esta "propuesta museal" un dinamismo y una omnipresencia que se consagran en casos como los aludidos, haciendo tangible cierta sensibilidad de la moda mexicana, que por momentos logra trascender los descalabros de décadas de eventos pocos dinámicos.

Las asignaturas pendientes pasan por las publicaciones formales -libros, artículos científicos, estudios de caso- en materia de moda en México, prácticamente inexistentes, así como una presencia más sistemática de este lenguaje en los museos y en los eventos de diseño formal, para dotar al discurso de mayor contundencia: En síntesis, el desarrollo de la moda como cultura, como identidad y como fuerza económica que incide en la manera en la que nos relacionamos con el entorno. 
